\title{
PENERAPAN PEMBELAJARAN BERBASIS MASALAH UNTUK MENINGKATKAN KEMAMPUAN BERPIKIR KRITIS MATEMATIKA SISWA
}

\section{(THE APPLICATION OF PROBLEM BASED LEARING MODEL TO INCREASE CRITICAL THINKING SKILLS OF STUDENTS)}

\author{
Ayu Astuti ${ }^{1}$, Harina Fitriyani ${ }^{2}$ \\ ${ }^{1}$ Pendidikan Matematika Universitas Ahmad Dahlan Yogyakarta, \\ ayuastuti535@gmail.com \\ ${ }^{2}$ Pendidikan Matematika Universitas Ahmad Dahlan Yogyakarta, \\ harina.fitriyani@pmat.uad.ac.id
}

\begin{abstract}
Abstrak
Penelitian ini adalah penelitian tindakan kelas dengan subjek siswa kelas $\mathrm{X}$ Lukis 1 SMK N 3 Kasihan Bantul tahun ajaran 2017/2018. Instrumen yang digunakan dalam penelitian ini adalah pedoman observasi dan tes. Pengumpulan data dilakukan dengan cara observasi dan tes. Hasil penelitian menunjukkan bahwa kemampuan berpikir kritis siswa mengalami peningkatan dari siklus I ke siklus II setelah dilaksanakan pembelajaran berbasis masalah. Peningkatan kemampuan berpikir kritis ditunjukkan oleh peningkatan setiap aspek kemampuan berpikir kritis serta nilai rata-rata kelas. Aspek memberi penjelasan sederhana yang dimiliki oleh siswa adalah 90,00\% (sangat tinggi), aspek membangun kemampuan dasar yang dimiliki oleh siswa adalah 63,33\% (sedang), aspek memberi penjelasan lanjut yang dimiliki oleh siswa adalah $72,00 \%$ (sedang), aspek strategi dan taktik yang dimiliki oleh siswa adalah $86,00 \%$ (tinggi) dan aspek menyimpulkan yang dimiliki oleh siswa adalah $68,00 \%$ (sedang) pada kondisi akhir.
\end{abstract}

Kata kunci: Pembelajaran Berbasis Masalah, Berpikir Kritis

\begin{abstract}
This research was classroom action research. Subject of research was the students of X Lukis 1 in SMK N 3 Kasihan Bantul in 2017/2018. This research was on two cycles and twice meeting of each. The instrument of the research was observation and test. Data collection was by using observation and test. The result of the research showed that critical thinking of students had increased from the first cycle to secont cycle by problem based learning. The increased in critical thinking showed by increased of each aspect. In critical thinking and man of the class given simp;e explanation aspect was 90,00\% (very high), built basic skill student aspect was 63,33\% (middle), given more detail aspect was $72,00 \%$ (middle). Strategy and tactics students aspect was $86,00 \%$ (high) and summary aspect was $68,00 \%$ (middle).
\end{abstract}

Keywords: Problem Based Learning, Critical Thinking

\section{PENDAHULUAN}

Tantangan dan perkembangan pendidikan di Indonesia pada masa yang akan datang semakin besar dan kompleks. Pendidikan merupakan aspek yang penting dalam pembangunan bangsa. Karakter suatu bangsa dibangun melalui pedidikan. Melalui pendidikan yang bermutu, suatu bangsa dapat menyongsong 
masa depan yang lebih baik. Kegiatan pendidikan tidak bisa diabaikan begitu saja, salah satu kegiatan pendidikan yang dapat dilakukan adalah dengan inovasiinovasi proses pembelajaran di sekolah.

Terkait dengan hal tersebut, upaya mengembangkan kemampuan dan keterampilan dalam pembelajaran telah dilakukan dengan peningkatan kualitas pembelajaran baik dari segi penugasan materi, penggunaan metode, penggunaan media maupun pengelolaan kelas yang kondusif. Dalam Peraturan Pemerintah Nomor 65 Tahun 2013 standar proses yang menyatakan bahwa proses pembelajaran pada satuan pendidikan diselenggarakan secara interaktif, inspiratif, menyenangkan, menantang, memotivasi peserta didik. Untuk itu setiap satuan pendidikan melakukan perencanaan pembelajaran, pelaksanaan proses pembelajaran serta penilaian proses pembelajaran untuk meningkatkan efesiensi dan efektivitas ketercapaian kopetensi lulusan.

Banyak faktor yang perlu diperhatikan dalam pelaksanaan proses pendidikan. Salah satunya adalah kualitas guru dan siswa sebagai pelaku utama di institusi pendidikan. Peran guru dalam pembelajaran sering kali salah diartikan dalam proses mengajar di kelas, sebagian menganggap bahwa guru di kelas sebagai pusat pembelajaran. Hal ini berdampak pada pada peran siswa dalam melaksanakan kegiatan pembelajaran, mereka terkesan sebagai pelengkap komponen proses belajar mengajar di sekolah yang hanya menerima dan mendengarkan apa yang disampaikan oleh guru tanpa ada peran serta dalam proses pembelajaran.

Pembelajaran yang efektif ketika guru dan siswa saling melengkapi, dimana guru bertugas merencanakan pembelajaran dan siswa adalah peserta didik yang akan mendapatkan pembelajaran dari guru. Ketika guru merencanakan pembelajarannya dengan sangat matang, maka terjadilah pembelajaran yang menantang siswa untuk berperan aktif menyampaikan pengetahuan dan pengalaman yang didapatkan dalam kehidupan nyata serta siswa dapat menghubungkannya dengan konsep-konsep yang diberikan guru.

Kerangka kompetensi abad 21 menunjukkan bahwa pengetahuan mata pelajaran pokok saja tidak cukup, melainkan siswa harus memiliki kopentensi yaitu : kemampuan berpikir kreatif-kritis, karakter kuat (bertanggung jawab, sosial, toleran, produktif, adaptif dan sebagainya), serta kemampuan memanfaatkan informasi dan berkomunikasi.

Matematika adalah suatu bidang studi yang perlu dipelajari karena hakikat matematika adalah pemahaman pada pola perubahan yang terjadi di dalam dunia nyata dan di dalam pikiran manusia secara holistik. Walaupun matematika beroperasi berdasarkan aturan-aturan yang perlu dipelajari, tetapi kegiatan belajar ditunjukan lebih dari hanya dapat melakukan operasi matematika sesuai dengan aturan-aturan matematika yang diungkapkan dalam bahasa-bahasa matematika. Tujuan belajar matematika adalah mendorong siswa untuk menjadi pemecah masalah berdasarkan proses berpikir kritis, logis, dan rasional.

Mata pelajaran matematika itu penting untuk dikuasi oleh siswa, sehingga pembelajaran matematika perlu disampaikan oleh guru dengan baik. Belajar matematika tidak hanya sekedar keterampilan menghitung melainkan juga kemampuan berpikir dan bernalar menjelaskan secara matematika dalam menyelesaikan masalah matematika. 
Berdasarkan hasil wawancara peneliti pada tanggal 10 April 2017 dengan guru matematika di SMK N 3 Kasihan Bantul, beliau menyebutkan bahwa siswa belum mampu mendeskripsikan konsep pada setiap materi yang diajarkan, kebanyakan siswa diam ketika ditanya terkait dengan materi yang diajarkan. Pada materi tertentu siswa mampu menyelesaikan soal latihan dengan mengikuti langkah-langkah ya ng telah diajarkan. Menurut beberapa siswa hal tersebut mempermudah siswa dalam memahami materi yang diajarkan. Siswa juga menyebutkan bahwa soal-soal yang terkait dengan kehidupan nyata dapat membuat mereka memahami materi yang diajarkan dengan mudah. Namun, tidak sedikit siswa menyatakan bahwa matematika adalah mata pelajaran yang sulit dan membosankan.

Berdasarkan hasil wawancara pada tanggal 15 agustus 2017 dengan guru matematika di SMK N 3 Kasihan Bantul diperoleh informasi bahwa siswa cenderung bosan mempelajari matematika dan tidak sedikit siswa masih menganggap bahwa matematika kurang menyenangkan karena sulit dalam memahaminya, terlebih pada materi matematika yang berkaitan dengan pemecahan masalah atau konsep dasar matematika. Guru juga menyebutkan bahwa metode pembelajaran yang digunakan juga masih menggunakan pembelajaran konvensional.

Selain itu, berdasarkan praktik magang terapan pada tanggal 7 Agustus - 4 september 2017 terlihat bahwa motivasi dan minat belajar siswa dalam pembelajaran matematika cenderung rendah, karena dari 22 siswa yang hadir hanya 10 siswa yang mengikuti proses pembelajaran. Hal tersebut menyebabkan prestasi belajar siswa rendah, terlihat dari rata-rata nilai UTS siswa kelas X dengan $K K M \geq 70$. Untuk lebih jelasnya nilai rata-rata UTS matematika siswa kelas $\mathrm{X}$ dapat dilihat pada tabel di bawah ini .

Tabel 1. Nilai Rata-Rata Kelas UTS Matematika

\begin{tabular}{clccc}
\hline No & Kelas & $\begin{array}{c}\text { Rata-Rata } \\
\text { UTS } \\
\text { Matematika }\end{array}$ & $\begin{array}{c}\text { Persentase } \\
\text { Siswa Yang } \\
\text { Tuntas }\end{array}$ & $\begin{array}{c}\text { Persentase Siswa } \\
\text { Yang Tidak } \\
\text { Tuntas }\end{array}$ \\
\hline 1 & X. Animasi & 58,15 & $25 \%$ & $75 \%$ \\
2 & X. DKV 1 & 68,09 & $56,25 \%$ & $43,75 \%$ \\
3 & X. DKV 2 & 59,44 & $29,41 \%$ & $70,59 \%$ \\
4 & X. DKV 3 & 55,25 & $9,37 \% \%$ & $90,63 \%$ \\
5 & X. Kayu 1 & 79,81 & $100 \%$ & $0,00 \%$ \\
6 & X. Kayu 2 & 33,57 & $0,00 \%$ & $100 \%$ \\
7 & X. Keramik & 34,2 & $0,00 \%$ & $100 \%$ \\
8 & X. Lukis 1 & 57,05 & $0,00 \%$ & $100 \%$ \\
9 & X. Lukis 2 & 41,88 & $2,94 \%$ & $97,06 \%$ \\
10 & X. Lukis 3 & 38,20 & $2,94 \%$ & $97,06 \%$ \\
11 & X. Textil & 31,80 & $0,00 \%$ & $100 \%$ \\
\hline
\end{tabular}

Peneliti telah melakukan penelitian pendahuluan dengan memberikan satu soal essay matematika, dimana soal tersebut berkaitan dengan indikator kemampuan berpikir kritis. Berdasarkan hasil penelitian pendahuluan yang dilakukan peneliti di kelas X Lukis 1 pada tanggal 21 November 2017 diperoleh skor pada setiap aspek yaitu memberikan penjelasan sederhana diperoleh $38,23 \%$ (sangat kurang), membangun kemampuan dasar diperoleh 0,39\% (sangat kurang), 
membuat penjelasan lanjut diperoleh $43,13 \%$ (sangat kurang), strategi dan taktik diperoleh 0,19\% (sangat kurang), serta menyimpulkan diperoleh (sangat kurang). Sedangkan untuk nilai rata-rata kelas kemampuan berpikir kritis diperoleh 19,25\% (sangat rendah).

Dengan demikian, diperlukan pembelajaran yang menarik yang dapat meningkatkan minat belajar siswa dan melatih siswa dalam memecahkan masalah matematika, serta memotivasi siswa dalam mengeksplorasikan kemampuan mereka sehingga diharapkan kemampuan bepikir kritis siswa dapat tersalurkan dan nantinya bisa berdampak positif pada prestasi belajar siswa. Berdasarkan kondisi tersebut, maka upaya yang dapat dilakukan yaitu inovasi pembelajaran matematika yang berpusat pada siswa, pembelajaran yang memberikan kesempatan kepada siswa untuk dapat meningkatkan hasil belajar dan mengembangkan kemampuan berpikir kritis siswa.

Pembelajaran berbasis masalah (PBM) merupakan model yang efektif untuk pembelajaran proses berpikir tingkat tinggi (Ratumanan,2015:249). Dalam pembelajaran PBM guru memberikan permasalahan dunia nyata sebagai suatu konteks bagi siswa untuk belajar tentang keterampilan memecahkan masalah. PBM banyak menggunakan pemecahan masalah sebagai aktivitas belajar dan memberikan kesempatan kepada siswa untuk berpikir kreatif, mengemukakan ide kritisnya, dan mempresentasikan hasil pekerjaan kepada temannya. Untuk itu, peneliti ingin melakukan sebuah penelitian tindakan kelas tentang Penerapan Model Pembelajaran Berbasis Masalah Untuk Meningkatkan Kemampuan Berpikir Kritis Matematika Siswa Kelas X SMK N 3 Kasihan Bantul.

Berdasarkan rumusan masalah di atas, yang menjadi tujuan penelitian ini yaitu penerapan model pembelajaran berbasis masalah dapat meningkatkan kemampuan berpikir kritis matematika siswa kelas X SMK N 3 Kasihan Bantul.

\section{KAJIAN TEORI}

Bell, Frederick H,(1978:108) menyebutkan bahwa "A concept in mathematics in an abstract idea which enables people to classify objects or events and to specify whether the objects and events are examples or nonexample of the abstract idea." Pendapat tersebut dapat dipahami bahwa sebuah konsep dalam matematika adalah sebuah gagasan abstrak yang memungkinkan orang untuk mengklasifikasikan suatu objek atau peristiwa tertentu dan untuk menentukan apakah objek dan kejadian tersebut merupakan contoh atau bukan contoh dari suatu gagasan abstrak matematika.

Selain itu, Thompson (1992) mendefinisikan dari sudut pandang para pelajar dan mereka yang mengetahui matematika menyatakan : "for many educated person, mathematics is a disciplone characterized by acciurateresult and infaliable procedures, whose basic elements are arithmetic operations, algebraic procedures, and geometric terms and theorems. For them, knowing mathematics is equivalent to being skillful in perfoming procedurs and being able to identify the basic concepts of the discipline" (dalam Malik Ibrahim, 2015:16).

Pendapat di atas dapat dipahami kurang lebih bahwa untuk beberapa pelajar, matematika merupakan sebuah jenis mata pelajaran dengan hasil yang akurat dan prosedur yang benar, yang unsur-unsur dasarnya berupa operasi aritmatika, proses aljabar, teorema-teorema dan terminologi geometri. Bagi mereka yang mengetahui matematika merupakan sama halnya dengan menjadi 
pandai dalam melakukan prosedur dan menjadi terampil dalam mengidentifikasi konsep-konsep dasar pada mata pelajaran matematika.

Sedangkan pada kerangka kompetensi abad 21 menunjukkan bahwa pengetahuan mata matematika siswa harus memiliki kopentensi kemampuan berpikir kreatif-kritis. Ruggiero (2011:19) menyebutkan inti dari berpikir kritis sebagai berikut: "The essence of critical thinking is evaluation. Critical thinking, therefore, may be defined as the process by which we test claims and arguments and determine which have merit and which do not. In other words, critical thinking is a search for answers, a quest. Not surprisingly, one of the most important techniques used in critical thinking is asking probing questions."

Kurang lebih pendapat di atas dapat dipahami bahwa berpikir kritis dapat didefinisikan sebagai proses mana yang kita nyatakan percobaan dan argumentasi dan menentukan mana yang lebih baik dan mana yang tidak. Dengan kata lain, berpikir kritis adalah suatu pencarian untuk menjawab suatu penyelidikan. Tidak jarang, salah satu dari tehnik yang paling utama yang digunakan dalam berpikir kritis adalah meminta menyelidiki pertanyaan.

Menurut Ennis (Rusyna, Adun, 2014:110) indikator keterampilan berpikir kritis terdiri dari lima jenis, yaitu : Memberikan penjelasan sederhana (elementary clarification); Membangun keterampilan dasar (basic support); Menyimpulkan (inference); Membuat penjelasan lanjut (advanced clarification); Mengatur strategi dan taktik (strategies and tactics).

Salah satu pembelajaran yang memiliki kelebihan mampu meningkatkan kemampuan berpikir kritis adalah pembelajaran berbasis masalah. Menurut Westwood Peter (2008:31) menyebutkan beberapa kelebihan dalam pembelajaran berbasis masalah sebagai berikut:

- Encourages self-direction in learing;

- Prepares students to think critically and analytically;

- Empowers students to identity, locate and use appropriate resources;

- Issues students are linked closely with the real world and are motivating for students;

- Active involvement in integrating information and skills from different disciplines;

- Knowledge and strategies acquired are likely to be retained and transferred to other leanring situations.

Pendapat di atas dapat dipahami bahwa kelebihan pembelajaran berbasis masalah yaitu sebagai berikut

- Menjadikan siswa untuk lebih percaya diri dalam belajar;

- Mempersiapkan kemampuan siswa dalam berpikir kritis dan analitis,

- Memberikan kebebasan kepada siswa untuk mengidentifikasi, mengalokasi dan menggunakan sumber yang sesuai,

- Masalah pembelajaran berkaitan dengan dunia nyata dan memotivasi siswa,

- Keterlibatan aktif siswa dalam pengembangan informasi dan kemampuan disiplin ilmu yang berbeda, serta 
- Pengetahuan dan strategi yang diperoleh dapat digunakan untuk pembelajaran yang lainnya.

Abdullah,Ridwan (2017:157) menyebutkan bahwa pembelajaran berbasis masalah juga telah dikembangkan sebagai suatu model pembelajaran dengan sintaks belajar sebagai berikut:

Tabel 2. Sintaks belajar PBM

\begin{tabular}{|c|c|c|}
\hline No & Fase & Kegiatan Guru \\
\hline 1 & $\begin{array}{l}\text { Memberikan orientasi permasalahan } \\
\text { kepada siswa }\end{array}$ & $\begin{array}{l}\text { Menyajikan } \\
\text { membahas tujuan permasalahan, } \\
\text { memaparkan kebutuhan logistik } \\
\text { untuk pembelajaran, memotivasi } \\
\text { siswa untuk terlibat aktif }\end{array}$ \\
\hline 2 & $\begin{array}{l}\text { Mengorganisasikan } \\
\text { penyelidikan }\end{array}$ & $\begin{array}{lr}\text { Membantu siswa dalam } \\
\text { mendefinisikan } & \text { dan } \\
\text { mengorganisasikan } & \text { tugas } \\
\text { belajar/penyelidikan } & \text { untuk } \\
\text { menyelesaikan permasalahan } & \end{array}$ \\
\hline
\end{tabular}

$\begin{aligned} \text { Pelaksanaan investigasi } & \begin{array}{l}\text { Mendorong siswa untuk } \\ \text { memperoleh informasi yang tepat, } \\ \text { melaksanakan penyelidikan, dan } \\ \text { mencari penjelasan solusi }\end{array} \\ 4 \quad \begin{array}{l}\text { Mengembangkan dan menyajikan } \\ \text { hasil }\end{array} & \begin{array}{l}\text { Membantu siswa merencanakan } \\ \text { produk yang tepat dan relevan, } \\ \text { seperti laporan, rekaman video, dan } \\ \text { sebagainya untuk keperluan } \\ \text { penyampaian hasil }\end{array}\end{aligned}$

5 Menganalisis dan mengevaluasi Membantu siswa melakukan proses penyelidikan $\quad$ refleksi terhadap penyelidikan dan proses yang mereka lakukan.

Dalam penelitian ini pembelajaran berbasis masalah dilaksanakan berdasarkan sintaks sebagai berikut:

- Fase 1: Memberikan orientasi permasalahan kepada siswa

Dalam fase 1 kegiatan guru adalah menyajikan permasalahan, membahas tujuan pembelajaran, memaparkan kebutuhan logistik untuk pembelajaran, memotivasi siswa untuk terlibat aktif, mengkaitkan materi pelajaran dengan kehidupan sehari-hari, mengkondisikan siswa dengan membagi kelompok.

- Fase 2: Mengorganisasikan siswa untuk penyelidikan

Dalam fase 2 kegiatan guru adalah membantu siswa dalam mendefinisikan suatu masalah dan melaksanakan penyelidikan untuk menyelesaikan permasalahan

- Fase 3: Pelaksanaan investigasi 
Dalam fase 3 kegiatan guru adalah mendorong siswa untuk memperoleh informasi yang tepat, melaksanakan penyelidikan, dan mencari penjelasan solusi

- Fase 4: Mengembangkan dan menyajikan hasil

Dalam fase 4 kegiatan guru adalah membantu siswa merencanakan hasil yang telah di diskusikan bersama untuk di presentasikan.

- Fase 5: Menganalisis dan mengevaluasi proses penyelidikan

Dalam fase 5 kegiatan guru adalah membantu siswa melakukan refleksi terhadap penyelidikan dan proses yang dilakukan siswa.

Berdasarkan deskripsi di atas peneliti dapat menyimpulkan bahwa pembelajaran berbasis masalah adalah model pembelajaran yang mengakomodasi keterlibatan siswa dalam pembelajaran serta dalam pemecahan masalah. Pembelajaran yang melibatkan permasalahan dunia nyata. PBM melibatkan siswa untuk aktif menggali pengetahuan, aktif mencari informasi baru, mengintegrasikan pengetahian baru dengan apa yang diketahuinya, mengorganisasikan informasi yang diketahui, dan menjelaskan pada teman yang lain serta mengevalusi solusi yang ditemukan.

\section{METODE PENELITIAN}

Penelitan ini menggunakan penelitian tindakan kelas (PTK). Suharsimi,Arikunto (2011:1) menyebutkan bahwa Penelitian Tindakan Kelas bertujuan untuk menyelesaikan masalah melalui suatu perbuatan nyata. Model penelitian yang digunakan peneliti adalah model Kemmis dan Mc Taggart yang terdiri dari beberapa siklus. Dalam penelitian ini dilaksanakan dua siklus dengan empat kali pertemuan. Menurut Somaday, Samsu (2013:41) masing-masing siklus terdiri dari empat langkah yaitu (1) perencanaan, (2) pelaksanaan, (3) pengamatan, dan (4) refleksi.

Penelitian ini dilaksanakan di SMK N 3 Kasihan Bantul dan waktu penelitian pada semester genap. Subjek penelitian adalah kelas X lukis 1 dan objek penelitian adalah peningkatan kemampuan berpikir kritis matematika. Tehnik pengumpulan data berupa tes tertulis, observasi dan dokumentasi, instrument utama adalah peneliti sendiri dan instrumen bantunya tes dan observasi. Validitas instrument menggunakan validitas konstrak (construct validity) Menurut sugiyono (2015: 177), "untuk menguji validitas kontrak dapat digunakan pendapat dari ahli." Tehnik analisis data yang digunakan untuk mengolah data hasil penelitian ini yaitu menggunakan tehnik analisis data kuantitatif. Menurut Sugiyono (2015:207) tehnik analisis data kuantitatif merupakan kegiatan dari seluruh responden atau sumber data lain terkumpul.

\section{PEMBAHASAN DAN HASIL}

Berdasarkan hasil tes kemampuan berpikir kritis pada siklus I dan siklus II di kelas X lukis 1, berikut persentase kemampuan berpikir kritis matematika pada siswa terdapat pada tabel berikut ini:

Tabel 3. Hasil Tes Kemampuan Berpikir Kritis

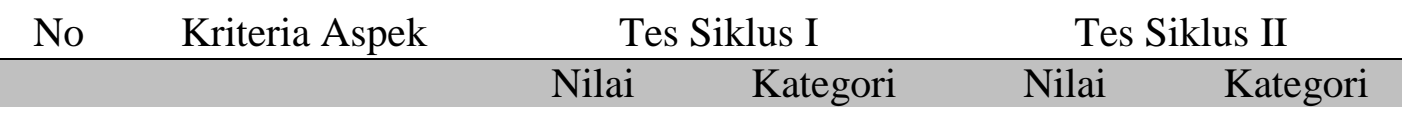




\begin{tabular}{|c|c|c|c|c|c|}
\hline 1 & $\begin{array}{l}\text { Memberikan } \\
\text { penjelasan } \\
\text { sederhana }\end{array}$ & $73,33 \%$ & Sedang & $90,00 \%$ & $\begin{array}{l}\text { Sangat } \\
\text { Tinggi }\end{array}$ \\
\hline 2 & $\begin{array}{l}\text { Membangun } \\
\text { keterampilan dasar }\end{array}$ & $47,73 \%$ & $\begin{array}{l}\text { Sangat } \\
\text { rendah }\end{array}$ & $69,33 \%$ & Sedang \\
\hline 3 & $\begin{array}{l}\text { Membuat } \\
\text { penjelasan lanjut }\end{array}$ & $62,00 \%$ & Rendah & $72,00 \%$ & Sedang \\
\hline 4 & $\begin{array}{l}\text { Mengatur strategi } \\
\text { dan taktik }\end{array}$ & $67,33 \%$ & Sedang & $86,00 \%$ & Tinggi \\
\hline \multirow[t]{2}{*}{5} & Menyimpulkan & $62,00 \%$ & Rendah & $68,00 \%$ & Sedang \\
\hline & Nilai Rata-rata & $62,48 \%$ & Rendah & & $70,07 \%$ \\
\hline
\end{tabular}

Berdasarkan tabel diatas aspek memberi penjelasan sederhana yang dimiliki oleh siswa adalah $73,33 \%$ (sedang) pada tes siklus I. Kemudian meningkat menjadi 90,00\% (sangat tinggi) pada tes siklus II. Pada aspek ini, indikator yang dilihat adalah kemampuan siswa dalam mengidentifikasi informasi suatu masalah. Pada tes siklus I siswa belum optimal dalam mengidentifikasi suatu masalah. Sebagaian siswa tidak menuliskan informasi apapun yang ada pada suatu masalah. Pada tes siklus II, siswa sudah dapat menuliskan infomasi yang ada pada suatu masalah, namun masih ada sebagian kecil siswa salah dalam menuliskan informasi yang ada.

Sedangkan aspek membangun kemampuan dasar yang dimiliki oleh siswa adalah 47,73\% (sangat rendah) pada tes siklus I. Kemudian meningkat menjadi $63,33 \%$ (sedang) pada tes siklus II. Pada aspek ini, indikator yang dilihat adalah kemampuan siswa dalam menggambar sketsa pada suatu masalah. Pada tes siklus I siswa belum optimal dalam menggambar sketsa. Sebagaian siswa tidak menggambarkan sketsa apapun . Pada tes siklus II, siswa sudah dapat menggambarkan sketsa yang sesuai dengan suatu masalah tersebut, namun masih ada sebagian kecil siswa salah dalam menggambarkan sketsa yang ada.

Untuk aspek memberi penjelasan lanjut yang dimiliki oleh siswa adalah $62,00 \%$ (rendah) pada tes siklus I. Kemudian meningkat menjadi 72,00\% (sedang) pada tes siklus II. Pada aspek ini, indikator yang dilihat adalah kemampuan siswa dalam memberikan penjelasan terkait dengan sketsa yang telah digambar. Pada tes siklus I siswa belum optimal dalam menjelaskan sketsa yang telah digambar. Sebagaian siswa tidak menjelaskan sketsa apapun . Pada tes siklus II, siswa sudah dapat menjelaskan sketsa yang sesuai dengan sketsa yang telah digambar, namun masih ada sebagian kecil siswa salah dalam menjelaskan sketsa yang ada.

Berdasarkan aspek strategi dan taktik yang dimiliki oleh siswa adalah 67,33\% (sedang) pada tes siklus I. Kemudian meningkat menjadi 86,00\% (tinggi) pada tes siklus II. Pada aspek ini, indikator yang dilihat adalah kemampuan siswa dalam merencanakan dan menyelesaikan masalah. Pada tes siklus I siswa belum optimal dalam merencanakan dan menyelesaikan masalah. Sebagaian siswa belum mampu merencanakan dan menyelesaikan masalah dengan benar. Pada tes siklus II, siswa sudah sudah mampu merencanakan dan menyelesaikan masalah dengan benar, namun masih ada sebagian kecil siswa salah merencanakan dan menyelesaikan masalah yang ada. 
Aspek menyimpulkan yang dimiliki oleh siswa adalah 62,00\% (rendah) pada tes siklus I. Kemudian meningkat menjadi $68,00 \%$ (sedang) pada tes siklus II. Pada aspek ini, indikator yang dilihat adalah kemampuan siswa dalam menyimpulkan masalah yang telah diselesaian. Pada tes siklus I siswa belum optimal dalam menyimpulkan masalah yang telah diselesaian. Sebagaian siswa belum mampu menyimpulkan masalah yang telah diselesaian dengan benar. Pada tes siklus II, siswa sudah sudah mampu menyimpulkan masalah yang telah diselesaian dengan benar, namun masih ada sebagian kecil siswa salah menyimpulkan masalah yang telah diselesaian yang ada.

Dilihat dari selilih perbandingan dari setiap aspek kemampuan berpikir kritis, aspek membangun ketrampilan dasar dan mengatur strategi dan taktik. Peningkatan aspek tersebut dari siklus I ke siklus II untuk aspek membangun ketrampilan dasar yaitu $21,6 \%$ dan untuk aspek mengatur strategi dan taktik $18,67 \%$. Hal tersebut dikarenakan pada siklus II siswa lebih teliti dalam memahami soal.

Jika dilihat berdasarkan nilai rata-rata kelas, pada siklus 1 nilai rata-rata kelas adalah $62,48 \%$ dengan kriteria rendah dimana terdapat $4 \%$ siswa yang memiliki kriteria kemampuan berpikir kritis sangat tinggi, 8\% siswa memiliki kriteria kemampuan berpikir kritis tinggi, 28\% siswa memiliki kriteria kemampuan berpikir kritis sedang, 44\% siswa memiliki kriteria kemampuan berpikir kritis rendah dan 16\% siswa memiliki kriteria kemampuan berpikir kritis sangat rendah. Terjadi peningkatan nilai rata-rata kelas pada tes siklus II nilai ratarata kelas adalah $77,07 \%$ dengan kriteria sedang dimana terdapat $12 \%$ siswa memiliki kriteria kemampuan berpikir kritis sangat tinggi, 40\% siswa memiliki kriteria kemampuan berpikir kritis tinggi, 28\% siswa memiliki kriteria kemampuan berpikir kritis sedang, 8\% siswa memiliki kriteria kemampuan berpikir kritis rendah, dan $12 \%$ siswa memiliki kriteria kemampuan berpikir kritis sangat rendah.

Berdasarkan uraian diatas, pembelajaran berbasis masalah dapat meningkatkan kemampuan berpikir kritis siswa. Tahap-tahap pembelajaran berbasis masalah menuntut siswa untuk mengembangkan kemampuan berpikir krtitis siswa. Pemberian soal dengan tingkat kesulitan relatif tinggi juga memberikan kontribusi yang penting dalam mengingkatkan kemampuan berpikir kritis. Disamping itu, siswa juga memberikan respon positif dengan diberikannya pembelajaran berbasis masalah.

\section{SIMPULAN}

Berdasarkan hasil penelitian yang sudah dilakukan pada setiap siklus dapat disimpulkan bahwa: Penerapan pembelajaran berbasis masalah dapat meningkatkan kemampuan berpikir kritis pada materi luas segitiga pada trigonometri siswa kelas X.Lukis 1 SMK N 3 Kasihan Bantul tahun ajaran 2017/2018. Hal tersebut dapat dilihat dari hasil tes kemampuan berpikir kritis, aspek-aspek yang meningkat dari kondisi awal yaitu aspek memberi penjelasan sederhana yang dimiliki oleh siswa adalah 73,33 (sedang) menjadi 90,00(sangat tinggi), aspek membangun kemampuan dasar yang dimiliki oleh siswa adalah 47,73 (sangat rendah) menjadi 63,33 (sedang), aspek memberi penjelasan lanjut yang dimiliki oleh siswa adalah 62 (rendah) menjadi 72,00 (sedang), aspek strategi dan taktik yang dimiliki oleh siswa adalah 67,33 (sedang) menjadi 86,00 
(tinggi) dan aspek menyimpulkan yang dimiliki oleh siswa adalah 62,00 (rendah) menjadi 68,00 (sedang) kondisi akhir. Sedangkan untuk nilai rata-rata kelas dari kondisi awal adalah 62,48 rendah) menjadi 77.07 (sedang) pada kondisi akhir.

\section{DAFTAR PUSTAKA}

Abdullah,Ridwan.(2017). Pembelajaran Saintifik untuk Implementasi Kurikulum 2013.Jakarta:Bumi Aksara.

Arikunto,Suharsimi. (2010). Penelitian Tindakan. Yogyakarta: Aditya Media.

Bell,Frederick H.(1978).Teaching and learing mathematic: in secondary school.Dubuque,Lowa:Wm.C.Brown.

Permendikbud.(2003).Undang-Undang No. 65 Tahun 2003 tentang Standar Proses Pendidikan Dasar dan Menengah.

Ruggiero,V.R.(2011).Beyond Feelings :A Guide To Critical Thinking, $\left(9^{\text {th }}\right.$ ed) Avenue of the America,NY:The McGraww Hill Companies,Inc.

Ratumanan.(2015).Inovasi Pembelajaran,Yogyakarta:Penerbit Ombak.

Rusyna,Adun.(2014).Keterampilan Berpikir:Pedoman Praktis para Peneliti Berpikir. Yogyakarta:Penerbit Ombak.

Somaday,Samsu. (2013). Penelitian Tindakan Kelas(PTK) . Yogyakarta: Graha Ilmu.

Sugiyono.(2015).Metode Penelitian Pendidikan:Pendekatan Kuantitatif,Kualitatif dan $R \& D$. Bandung: Alfabeta.

Wesrwoods,Petter (2008). What teachers need to know about. Australia: ACER Press. 